\title{
Specific Issues of Legal Support for Prevention and Preclusion of the Juvenile Delinquency and Crime (Federal and Regional Aspects)
}

\author{
Anghelina I. ROTAR \\ Senior Lecturer \\ Department of Jurisprudence \\ North-Eastern State University \\ 13 Portovaya Str., Magadan, 685000, Russia \\ angel-wind@list.ru
}

\begin{abstract}
The society in every single country, as well as the world community, has been always concerned with the problem of protecting the legitimate rights and interests of children. Contemporary concept of prevention of the juvenile delinquency and crime rests on principles of the integrated interaction of the authorities engaged in preventive work. Strengthening of the activities by the state bodies and officials in the field of regulating the prevention of juvenile delinquency and crime should be the primary objective of the state juvenile policy. In the context of this research, the state programs and strategies being of the paramount importance for the designated field, as well as the laws, regulations, programs in Magadan Oblast adopted in the framework of the preventive work implementation with the minors are studied. Additionally, specified are the activities conducted by the individual agencies and institutions of the system responsible for prevention of the juvenile neglect and delinquency in Magadan Oblast. The author employed dialectical, statistical, and the system-based structural, formal logical and other methods of scientific knowledge.
\end{abstract}

Keywords: minors; delinquency and crime prevention; preventive system.

\section{Introduction}

Relevance. Over the past two decades, the issues pertained to the rights and interests of the minors have been the subject of the ongoing discussion in our country. This is due to the heightened attention paid by the government to this category of citizens, with ensuring and protecting their rights and freedoms being the priority. It is worth mentioning, that scientists, state officials and enforcement officers emphasize the issues of juvenile justice and politics; the administrative and legal regulation of prevention of juvenile delinquency and crime; the role of particular state bodies and officials in juvenile crime prevention; the issues related to combating juvenile delinquency; the specifics of criminal proceedings and imposition of sentence not related to social isolation, as well as the reformation of the convicted minors.

The personality traits of adolescents, namely the age, mental individualities and the necessity to shift from a punitive reaction of the state towards adolescent offenses to a restorative justice system, led to the disengagement of 'the juvenile justice' from the criminal one.

This research purpose lies in identification of the legal regulation specifics as regards the issues of prevention and suppression of the juvenile delinquency at the federal and regional levels, as well as the practice of these acts application.

The research objectives are determined by the research subject matter and its purpose, and are as follows:

- consideration of the federal substantive legal framework governing prevention and suppression of the juvenile delinquency; 
- consideration of the regulatory framework governing prevention and suppression of the juvenile delinquency in Magadan Oblast;

- analysis of the strategic planning acts of Russia and Magadan Oblast on prevention of the juvenile neglect and delinquency;

- specification of certain socially significant activities conducted in Magadan Oblast in the framework of the problem as stated;

- consideration of certain aspects of the enforcement activities by the entities involved in prevention of the juvenile neglect and delinquency.

Research Methods. The author employed analytical, dialectic, statistical methods, as well as interviewing and the system-based structural, and other methods of scientific knowledge.

The research outcome consist in obtaining the data on the activities of the entities involved in prevention of the juvenile neglect and delinquency in Magadan Oblast inclusive of the statistical data on measures and ways taken in order to strengthen their activities.

\section{Discussion}

The carried out research is analytical in its nature, and stands out for its novelty, since no other similar studies had been conducted (in Magadan Oblast). The studies on juvenile matters are widespread, and are carried out in various directions and focus on various aspects of prevention of the juvenile neglect and delinquency.

Among the fundamental international documents that formalize the principles of activity and particularities of the juvenile justice are the following: United Nations Standard Minimum Rules for the Administration of Juvenile Justice (the Beijing Rules), 1985 (United Nations Standard Minimum Rules, 1985); Convention on the Rights of the Child (Convention on the Rights of the Child, 1989) (New York, November 20, 1989); United Nations Guidelines for the Prevention of Juvenile Delinquency (the Riyadh Guidelines), 1990 (United Nations Guidelines for the Prevention of Juvenile Delinquency, 1990).

These international instruments entrench the priority of educational and other social and legal measures in various law branches towards the liability of prosecution. They are designed to guarantee provision of the minimum guarantees in view of the rights and interests of the minors, and determine the state policy in this field in general.

Nowadays, all contemporary countries enact legislation, programs and pursue policies on prevention of the juvenile delinquency, and on principles of the juvenile justice in consideration of the aforementioned international norms.

In the United States of America (USA), the Juvenile Justice and Delinquency Prevention Act (JJPDA) has been in force since 1974, and prevention of the juvenile delinquency remains one of the justice system objectives. The Office of Juvenile Justice and Delinquency Prevention was established (under the US Department of Justice) to support the local and state crime prevention efforts and strengthen the juvenile justice. Besides, in furtherance of this direction, special programs are launched, e.g. the Safe Futures Program aimed at reducing the juvenile delinquency and violence against the youth. With the support of the Safe Futures funds, the probation services and mentoring programs for the youth are introduced in some states, as well as in the specialized centers (Morley et al., 2000). The youth rehabilitation service conducts ample activities in USA targeting the reduction in risk of the repletion of crimes committed by the minors and held accountable previously (Xu et al., 2019).

By Decree of the President of Russia dd. May 29, 2017 no. 240 (Decree of the President of Russia dd. May 29, 2017 no. 240 on Pronouncing the years of 2018-2027 as the Decade of Childhood in the Russian Federation, 2017), the years of 2018-2027 are defined as the Decade of Childhood, and 
that manifests particular significance of the interests of children and adolescents, and the need to nationwide and steadily take into account the priority of the interests of children.

By Resolution of the Government of the Russian Federation (RF) (Resolution of the Government of the Russian Federation dd. July 06, 2018 no. 1375-r. on Implementation of the key actions plan until the year of 2020 within the context of the Decade of Childhood, 2018), the key actions plan until the year of 2020 to be carried out within the context of the Decade of Childhood was approved, and includes quite a significant list of programs, measures, roadmaps, practices, elaboration and approval of the priority projects. In particular, foreseen is the implementation of such measures as those aimed at promoting a healthy lifestyle in children and the youth; measures to restrain the criminalization of the adolescents; the provision of social support to the minors condemned to sentences without social isolation; the support towards humanization of the juvenile prosecution for those who committed crimes of light and medium gravity; the development and implementation of the preventive work program with the minors in places of deprivation of liberty and with their parents for the purposes of re-socialization and adaptation to family life.

Pursuant to Paragraph 2 of Article 2 of the Federal Law (hereinafter referred to as the Federal Law) on Fundamental Principles of the System for the Delinquency Prevention in the Russian Federation (Federal Law dd. June 23, 2016 no. 182-FZ on Fundamental Principles of the System for the Delinquency Prevention in the Russian Federation, 2016), the delinquency prevention is a combination of social, legal, organizational, informational and other measures aimed at identifying and eliminating the causes and conditions conducive to committing offenses, and also on provision of the educational influence upon individuals in order to disallow committing offenses or antisocial behavior.

The crime preventive system (Item 3 of Article 2) represents the total of crime prevention entities, individuals involved into crime prevention, and crime prevention measures undertaken by them, as well as the main principles of the activities coordination and crime prevention monitoring.

Currently, the government administrates the system of state agencies that are entrusted with the powers to carry out the preventive work, to disallow and preclude offenses (crimes) and neglect.

\section{The crime prevention entities are as follows:}

1) Federal executive agencies;

2) Prosecution authorities of the Russian Federation;

3) Investigation authorities under the Investigative Committee of the Russian Federation;

4) State government bodies of the constituent entities of the Russian Federation;

5) Local government authorities.

Pursuant to Article 4 of the Federal Law dd. June 24, 1999 no. 120-FZ on Fundamental Principles of the System for the Juvenile Neglect and Delinquency Prevention, the preventive system of the juvenile neglect and delinquency comprises as follows:

- Government committees for affairs of the minors and protection of their rights,

- Management authorities for social protection of the population,

- Federal agencies of the state power and state government bodies of the constituent entities of the Russian Federation conducting state administration in the field of education,

- Local government authorities responsible for educational management,

- Custody and guardianship agencies,

- Youth authorities,

- Government health agencies,

- Public employment services,

- Internal affairs agencies, 
- Correctional system facilities (investigatory detention centers, educational colonies and probation departments).

Children's Rights Commissioner for the President of the Russian Federation, Children's Rights Ombudsmen in the regions, public associations and voluntary service organizations take part in preventive activities.

Activities of the State committees for the affairs of the minors are regulated at the federal level by Decree of the Presidium of the Supreme Council of the Russian Soviet Federative Socialist Republic (RSFSR) dd. June 03, 1967 on Ratification of the Regulation on Committees for the affairs of the minors. At the regional level, they are regulated by the legislation issued by the bodies of the constituent entities of the Russian Federation. By Resolution of the Government of the Russian Federation dd. November 6, 2013 no. 995, the Approximate Regulation on Committees for the Affairs of the Minors was ratified (Resolution of the Government of the Russian Federation dd. November 6, 2013 no. 995 on Enactment of approximate regulation on committees for the affairs of the minors and protection of their rights, 2013).

In overall, it can be concluded that the administrative and legal status of the committees for the affairs of the minors is defined. Nonetheless, the need for passing the federal law governing the powers and procedures of the committees for the affairs of the minors is evident.

At the level of the constituent entities of the Russian Federation, there are committees presided by the highest-in-rank executive official of the constituent entity, with their authority extending only within the region.

At the municipal level, the local governments form committees to carry out activities throughout the districts and cities, which are largely responsible for the entire range of liabilities to exercise the powers vested on such entities by virtue of the law. They, above all, review the cases on administrative offenses as regards the minors and their parents, carry out preventive activities among the 'troubled youth', and coordinate the work of all entities within the preventive system (Kostenko, 2018).

For the purposes of the legislative supervision of activities of the committees for the affairs of the minors and protection of their rights, the National Strategy provides for drafting of the federal law on the committees for the affairs of the minors and protection of their rights and which would define the place and role of the committees among the agencies in the preventive system. The National Strategy ensures the pattern for implementation arrangements in view of the human rights, coordinating and preventive functions of the committees in order to protect the rights of children; ensures protection from violence and all forms of infringement on their health and survival; develops socialization and rehabilitation measures for the minors; empowers the committees with the right to keep a personified data bank of the unsupervised minors, children and families experiencing socially dangerous situations; exempts the committees from performing the functions of the voluntary jurisdiction entity.

Particular attention should be drawn to the issues of legal regulation of the activities for the prevention of crime and delinquency, with enforcement thereof, in Magadan Oblast.

Outlined below are the key achievements representative of the administration and protection of the rights and interests of the minors in our region.

By virtue of the program on Prevention of Delinquency in the municipality of the City of Magadan in 2006-2010 (Purpose-oriented Program on Prevention of Delinquency in the municipality of the City of Magadan in 2006-2010: Resolution of the Magadan City Council dd. November 17, 2006 no. 93-D, 2007), the interagency cooperation order was established to prevent crimes and delinquencies among the minors. Owing to the material and technical base upgrade and creation of 
the volunteer public order control, the criminal conviction rate increased. The number of grave offences, as well as crimes committed by the minors, decreased.

In 2010, the public hearings were held in the city hall of Magadan, in the course of which the positive results achieved by the entities involved into the prevention work were discussed, i.e. by way of alternative to the asocial lifestyle of the youth and adolescents, a set of measures aimed at organizing labor and leisure activities was proposed. The youth employment agency was established and is successfully up and running. There is a record of the regularly conducted annual joint interagency preventive activities under the names School, Family, Teenager, as well as the visiting events that contributed to the identification of citizens in need of the social support.

The coordinated interaction between the institutions and departments is organized to build the system for prevention of the juvenile neglect and delinquency. In educational institutions of the city of Magadan, a database of the minors who do not attend school is regularly updated. The pupils undergo verification against those registered with the school, with the Internal affairs agency of the city of Magadan, with the committee for affairs of the minors and protection of their rights under the city hall of Magadan.

In order to prevent the return to crime, those adolescents who are registered with the Internal affairs agency of the city of Magadan, are entrusted to the mentors from among the most experienced personnel (On holding Public Hearings in line with the long-term purpose-oriented city program implementation on Delinquency Prevention in the municipality of the City of Magadan in 20112013: Resolution of the Magadan City Hall dd. August 24, 2010 no. 2515, 2010).

Starting 2014, implementation of the State Program on Safety, Prevention of Delinquency, Corruption and Combating the Illicit Drug Trafficking in Magadan Oblast for 2014-2018 was in effect as enacted by Decree of Magadan Oblast Administration dd. November 20, 2013 no. 1144pa. The key message of the program was the prevention of the drug addiction spread among the adolescents.

The city purpose-oriented the Youth of Magadan program pursue the goal of implementing the youth policy in the city. The purpose is to introduce the healthy and meaningful leisure time for the youth; take measures to prevent drug addiction, alcoholism and crimes among the youth, involve them into the public order maintenance to reduce the total of the juvenile delinquency cases and curb the increase in drug use among the youth.

Currently, the Youth of Magadan program for 2018-2022 is in force (On enactment of the Youth of Magadan Program for 2018-2022: Resolution of the Magadan City Hall dd. September 18, 2017 no. 3026,2017 ), and outlines the negative trends, achieved results, and the key lines of activity for the next 4 years.

Regulatory acts of Magadan Oblast on prevention of the juvenile neglect and delinquency are as follows:

Act of legislation of Magadan Oblast dd. July 17, 2018 no. 2290-OZ on Specific Issues of Crime Prevention in Magadan Oblast (Act of legislation of Magadan Oblast dd. July 17, 2018 no 2290-OZ on Specific Issues of Crime Prevention in Magadan Oblast (rev. dd. March 18, 2019), 2018) determines the powers of the state authorities of Magadan Oblast in the field of the crime prevention in Magadan Oblast, and regulates certain issues in the field of crime prevention.

Act of legislation of Magadan Oblast dd. November 24, 2012 no. 1573-OZ (rev. dd. May 03, 2018) on Measures to Prevent the Juvenile Neglect and Delinquency (enacted by the Magadan Oblast Council (Duma) on October 31, 2008) (Act of legislation of Magadan Oblast dd. November 24, 2012 no. 1573-OZ on Measures to Prevent the Juvenile Neglect and Delinquency (enacted by the Magadan Oblast Council (Duma) on October 31, 2008) (rev. dd. May 03, 2018), 2008). 
Act of legislation of Magadan Oblast dd. December 24, 2012 no. 1573-OZ (rev. dd. May 3, 2018) on the State Youth Policy in Magadan Oblast (enacted by the Magadan Oblast Council (Duma) on December 24, 2012) (Act of legislation of Magadan Oblast dd. December 24, 2012 no. 1573-OZ on the State Youth Policy in Magadan Oblast (rev. dd. May 3, 2018), 2012).

Decree of the Government of Magadan Oblast dd. May 29, 2014 no. 453-pp (rev. dd. August 08, 20019) on the Government Committee of Magadan Oblast for the Affairs of the Minors and the Protection of their Rights (Decree of the Government of Magadan Oblast on the Government Committee of Magadan Oblast for the Affairs of the Minors and the Protection of their Rights dd. May 29, 2014 no. 453-pp (rev. dd. August 08, 2019), 2014).

Decree of the Government of Magadan Oblast dd. June 22, 2017 no. 594-pp on Ratification of the Norms and Procedure on Provision the Minors registered with the Institutions Administrating Prevention of the juvenile neglect and delinquency in Magadan Oblast with Free Food, Outfit, Shoes and Textile Products (Decree of the Government of Magadan Oblast dd. June 22, 2017 no. 594-pp on Ratification of the Norms and Procedures on Provision the Minors registered with the Institutions Administrating Prevention of the juvenile neglect and delinquency in Magadan Oblast with Free Food, Outfit, Shoes and Textile Products, 2017).

Resolution of the Governor of Magadan Oblast dd. August 08, 2016 no. 174-p (rev. dd. February14, 2018) on Interagency Committee for the Prevention of Offenses and Procedures in Emergency Situations in Recreation Places for Children to Ensure Safety of the Organized Groups of Children along the Routes for all means of transport (in conjunction with Regulation on Interagency Committee for the Prevention of Offenses and Procedures in Emergency Situations in Recreation Places for Children to Ensure Safety of the Organized Groups of Children along the Routes for all means of transport) (Resolution of the Governor of Magadan Oblast dd. August 08, 2016 no. 174-p (rev. dd. February14, 2018) on Interagency Committee for the Prevention of Offenses and Procedures in Emergency Situations in Recreation Places for Children to Ensure Safety of the Organized Groups of Children along the Routes for all means of transport (in conjunction with Regulation on Interagency Committee for the Prevention of Offenses and Procedures in Emergency Situations in Recreation Places for Children to Ensure Safety of the Organized Groups of Children along the Routes for all means of transport, 2016).

Decree of the Government of Magadan Oblast dd. August 21, 2017 no. 829-pp (rev. dd. June 29, 2018) on Ratification of the State Program of Magadan Oblast on Safety, Prevention of Delinquency, Corruption and Combating the Illicit Drug Trafficking in Magadan Oblast for 20182024 (Decree of the Government of Magadan Oblast dd. August 21, 2017 no. 829-pp on Ratification of the State Program of Magadan Oblast on Safety, Prevention of Delinquency, Corruption and Combating the Illicit Drug Trafficking in Magadan Oblast for 2018-2024 (rev. dd. June 29, 2018), 2017).

This State Program includes two sub-programs:

1) Sub-program 1 on Prevention of Offenses and Public Safety Maintenance in Magadan Oblast for 2018-2024;

2) Sub-program 2 on Comprehensive Measures to Combat Drug Abuse and Illicit Drug Trafficking in Magadan Oblast for 2018-2024.

Sub-program 1 embraces the activities as such:

- prevention of the delinquency in public places and streets;

- prevention of the juvenile neglect and delinquency;

- prevention of the alcoholism and promotion of a healthy lifestyle and social involvement. 
Implementation of the measures for prevention of the juvenile neglect and delinquency provides for carrying out an action plan involving the parent committees of schools, educational authorities, families and committees for the affairs of the minors and protection of their rights in part of the neglect and prevention of the juvenile delinquency.

Implementation of the measures for prevention of the alcoholism, promotion of a healthy and socially active lifestyle includes an action plan contributing to the reorientation of the population towards a sober and healthier lifestyle; fashioning intolerance in the society towards manifestations of the alcohol abuse; launching incentives to boost public initiatives aimed at improving public health.

Sub-program 1, among others, embraces the activities as such:

- organizational and legal measures to counteract the drug use without medical prescription and illicit trafficking thereof;

- prevention of the drug abuse inclusive of comprehensive anti-drug propaganda and anti-drug education, and promotion of a healthy lifestyle among the population of Magadan Oblast.

The key campaign on Organizational measures to combat the drug abuse and their trafficking implies monitoring of the drug situation in Magadan Oblast, medical checks, holding seminars, staffing and advanced training of medical personnel.

Campaign on Prevention of the drug abuse implies comprehensive anti-drug propaganda and antidrug education, and promotion of a healthy lifestyle among the population of Magadan Oblast, and targets the following aspects:

- fashioning the a negative attitude in the society towards non-medical use of the narcotic drugs, particularly through the active anti-drug propaganda and countering the promotion and illegal advertising of the narcotic drugs and other psychoactive substances, raising public awareness of the negative consequences of the non-medical drug use and liability for participating in illicit trafficking thereof, and spreading the competent information policy in the media;

- establishing and stimulation of development and its government support for the activities carried out by the voluntary youth anti-drug movement, public anti-drug associations and organizations involved in the drug addiction prevention;

- building-up the psychological immunity to the drug use in schoolchildren and the youth.

In Magadan Oblast, the mentioned programs are implemented by the government agencies, whose responsibilities include implementation of the preventive activities involving the management of schools, vocational schools and colleges, Northeastern State University, and volunteer youth movements.

By enactment of various decrees of the government bodies of Magadan Oblast and the city of Magadan, the numerous programs are designed to organize the summer holidays for children, their health improvement and employment, and setting up of the temporary summer employment for the minors.

It should be noted, that in our city the issues related to the interests of the minors are discussed at open public events. Thus, on November 22, 2019, the VI Open Forum Children are our Future. Family-School-Society was held, in the course of which the floor was taken by D. Gekhova, senior assistant to Prosecutor of Magadan Oblast for supervision of the law enforcement on the minors; V. Baida, Deputy Head of Division of Plenipotentiaries for Police and Juvenile Affairs under the Ministry of Internal Affairs of Russia for Magadan Oblast; E. Gavrilova, executive secretary to Government Committee of Magadan Oblast for the Minors and Protection of their Rights, Head of the Department for the Minors and Protection of their Rights; D. Pavlik, Ombudsman for the 
Children's Rights in Magadan Oblast; I. Gornostaeva, First Deputy Minister of Education of Magadan Oblast; I. Popova, Deputy Minister of Labor and Social Policy of Magadan Oblast, and other speakers.

In their speeches, the officials touched upon positive trends when implementing the legislative norms towards the minors, as well as the state programs in the fields of education, setting up the adolescent employment and leisure activities, prevention of the juvenile delinquency, and protection of the rights and legitimate interests of the minors. The statistical data on the activities of the prosecutor's office, executive authorities, law enforcement agencies, public organizations were presented. The most topical issues among those discussed were as follows:

- identification of adolescents in socially dangerous situations, their registration, further supervision of such minors and their families, provision of the psychological assistance and drug dependency treatment, their participation in leisure activities;

- bringing parents to administrative responsibility for the improper performance of parental duties;

- holding meetings, lectures, workshops in educational institutions, schools, summer camps (on various topics like administrative and criminal liability; advisal of rights and obligations; raising awareness of harmful effects of alcohol, drugs, etc.);

- strengthening the interagency cooperation, coordination of the activities run by the authorities and institutions of prevention as the prerequisite for efficient performance;

- providing assistance to adolescents in life management, employment, psychological assistance, provision of housing for the children left without parental care and orphans;

- creation of the unified automated data bank to store various information and data from the authorities and institutions of the preventive system (including registration, prosecution, relocation of families and the minors, restriction or deprivation of parental rights, etc.) that will be accessible by all entities exercising the prevention.

In particular, some aspects of the practical activities carried out by the entities exercising the prevention, should be addressed to.

The Government Committee of Magadan Oblast on the affairs of the minors and protection of their rights is a collegial public body established to coordinate the work of agencies and services of the juvenile neglect and delinquency preventive system in order to coordinate their activities. In Magadan Oblast, there are 9 municipal committees for the affairs of the minors, and all of them interact with a great number of authorities and institutions. The focus is on the individual preventive work including assistance in life management, household arrangements, conducting medical checks and treatment for the children, organizing their leisure time and leisure activities, and giving lectures. The Committee on the affairs of the minors registers and works with families in the socially dangerous situations. In 2019 the number of such families decreased by $17.9 \%$ (from the report by Elena Gavrilova, Head of the Department for the Minors and Protection of Their Rights under Governor's Office and Government of Magadan Oblast, the VI Open Forum Children are our Future. Family-School-Society).

The main form of the committee work is meetings that take place once a fortnight. At committee meetings, the administrative matters are discussed, and the decisions are made in view of the minors and the citizens who improperly perform parental duties. Issues to be discussed also comprise those on the performance of the preventive system entities, on carrying out the individual scheduled interaction in relation to the families in socially dangerous situations. Parents (or lawful guardians) are prosecuted for the offenses committed by the children, as well as for evading parental duties, unwillingness to provide proper supervision and care for the children, and running household under the unsanitary conditions. 
At the committee meetings, the families are identified in which parents recourse to alcohol and drug abuse. This information is transmitted to the drug dependence clinic to seek patronage over such families and conduct preventive sessions with them and subsequent monitoring thereof. In 2019 (January to September), the information on 26 families was gathered for further medical and social care. All parents who address the committee meetings are provided with various forms of leisure activities, assistance in ensuring summer employment, and specialist advice.

The Commission investigates into the reasons for the violation of children's rights to get access to education, analyzes the causes of family problems, makes decisions on individual preventive work to change the situation in the family, and takes measures to protect the rights and legitimate interests of the minors.

For the 9 months of 2019, 60 decisions were made on individual preventive work with the families and minors, and relevant instructions were given to eliminate the causes and conditions that result in commitment of the crimes and offenses, and to normalize intra-family relations.

For the 9 months of 2019, the committee reviewed 509 administrative cases of which 161 administrative offenses were committed by the adolescents.

In order to prevent family dysfunction on a yearly basis, the committee runs an interagency campaign called School aimed at identifying children of the school age and at risk of not starting school, and providing them assistance with education services. As a result, 47 families were checked.

The Ombudsman for the Children's Rights in Magadan Oblast deals with various issues in line with the rights and interests of the minors in Magadan Oblast, participates in implementation of the unified state policy in the field of ensuring and protecting the rights and legitimate interests of children, and participates in activities to prevent the juvenile neglect and delinquency. The Ombudsman carries out their activities on the grounds of the Constitution of the Russian Federation, Federal Law of the Russian Federation dd. December 27, 2018 no. 501-FZ on Ombudsman for the Children's Rights in the Russian Federation, Legislative Act of Magadan Oblast dd. July 22, 2015 no. 1923-O (rev. dd. April 30, 2019) on Ombudsman for the Children's Rights in Magadan Oblast (On Ombudsman for the Children's Rights in Magadan Oblast: Legislative Act of Magadan Oblast dd. July 22, 2015 no. 1923-O, 2015).

While fulfilling the associated duties, the Ombudsman for the Children's Rights, exercises the following powers:

- consideration of appeals by citizens (parents, guardians, other individuals);

- organization of offsite visiting receptions of citizens in the districts of Magadan Oblast, including the remote areas;

- provision of consultations on various issues (family, leisure and employment, on offenses and restricted information access);

- participation in different promotional events, e.g., Pay Alimony campaign; social events (with the disabled children; families living in the detached-house suburbs and experiencing difficulties in life situations); legal education of the minors; in executive panels and meetings of and cross-regional events; pays visits to the state educational and health institutions.

The Ombudsman for the Children's Rights in Magadan Oblast is involved in solution of the urgent and crucial issues in view of the rights and legitimate interests of children, families with children, including but not limited to the following: school conflicts, orphan matters (including housing issues), cases of the children with disabilities, safety of the urban environment (comprising identification of harmful objects and addressing issues of stray dogs), and others. 
Sufficient consideration is given to the interagency cooperation, in particular, in view of signing the agreements with various preventive authorities on strengthening the interagency cooperation.

The Juvenile Affairs Division under the Office of the Ministry of the Interior (hereinafter referred to as UMVD) of Russia in Magadan Oblast is directly involved in prevention of the juvenile neglect and delinquency in our region (Table 1).

According to the statistical data on the juvenile delinquency situation in Magadan Oblast, our region is ranked as per the ministerial statistical estimates against the weighted mean value of the estimated indicators for the territorial agencies of the Ministry of Internal Affairs of Russia (the total of the minors who committed crimes per 1 thousand minors of 14-17 years old) (Russian Ministry of Internal Affairs in Magadan Oblast., 2019):

- for 2016: 76 out of 84 constituents of the RF (6 out of 9 for the Far Eastern Federal District (hereinafter referred to as the Far East);

- for 2017: 81 out of 84 constituents of the RF ( 8 out of 9 for the Far East);

- for 2018: 49 out of 84 constituents of the RF ( 2 out of 11 for the Far East);

- for 10 months of 2019: 72 constituents of the RF (7 out of 11 for the Far East).

Table 1. Total of the minors on preventive maintenance registered with the agencies of internal affairs

\begin{tabular}{|c|c|c|c|c|c|}
\hline & & 2016 & 2017 & 2018 & $\begin{array}{l}10 \text { мес. } \\
2019\end{array}$ \\
\hline \multicolumn{2}{|c|}{$\begin{array}{l}\text { Total of the minors on preventive maintenance with the } \\
\text { internal affairs agencies }\end{array}$} & 307 & 333 & 240 & 232 \\
\hline \multirow{5}{*}{ including } & aged $14-15$ & 85 & 119 & 90 & 95 \\
\hline & aged $16-17$ & 103 & 78 & 62 & 71 \\
\hline & brought up in single-parent families & 161 & 139 & 122 & 127 \\
\hline & $\begin{array}{l}\text { brought up by guardians, care-givers, in } \\
\text { foster families }\end{array}$ & 19 & 12 & 5 & 5 \\
\hline & $\begin{array}{l}\text { brought up in orphanages, boarding } \\
\text { schools }\end{array}$ & 1 & 4 & 104 & 8 \\
\hline
\end{tabular}

The greatest number of the committed crimes is of the pecuniary type, theft and hijacking of means of transport (Table 2).

Table 2. Share and total of the delinquencies and crimes committed by the adolescents

\begin{tabular}{|c|c|c|c|c|}
\hline & 2016 & 2017 & 2018 & $\begin{array}{l}10 \text { мес. } \\
2019\end{array}$ \\
\hline $\begin{array}{l}\text { Total of administrative offenses committed by the } \\
\text { minors }\end{array}$ & 139 & 126 & 104 & $\begin{array}{l}112 \\
+13.1\end{array}$ \\
\hline Total of crimes committed by the minors & $\begin{array}{l}101 \\
-8.2\end{array}$ & $\begin{array}{l}127 \\
+25.7\end{array}$ & $\begin{array}{l}74 \\
-41.7\end{array}$ & $\begin{array}{l}64 \\
-1.5\end{array}$ \\
\hline $\begin{array}{l}\text { Share of the crimes committed by the adolescents } \\
\text { among all solved, in } \%\end{array}$ & 5.2 & 7.1 & 4.6 & 4.6 \\
\hline theft & $\begin{array}{l}67 \\
-11.8\end{array}$ & $\begin{array}{l}73 \\
+9.0\end{array}$ & $\begin{array}{l}42 \\
-42.5\end{array}$ & $\begin{array}{l}37 \\
-7,5\end{array}$ \\
\hline hijacking of means of transport & $\begin{array}{l}14 \\
+27.3\end{array}$ & $\begin{array}{l}22 \\
+57.1\end{array}$ & $\begin{array}{l}3 \\
-86.4\end{array}$ & $\begin{array}{l}11 \\
+266.7\end{array}$ \\
\hline robbery & 3 & $\begin{array}{l}10 \\
+233.3\end{array}$ & $\begin{array}{l}6 \\
-40.0\end{array}$ & $\begin{array}{l}4 \\
-20.0\end{array}$ \\
\hline illicit drug trafficking & $\begin{array}{l}3 \\
-25.0\end{array}$ & $\begin{array}{l}4 \\
+33.3\end{array}$ & $\begin{array}{l}6 \\
+50.0\end{array}$ & 0 \\
\hline Total of grave and especially grave crimes committed & 25 & 32 & 13 & 14 \\
\hline
\end{tabular}


III International Theoretical and Practical Conference "The Crossroads of the North and the East (Methodologies and Practices of Regional Development)”

\begin{tabular}{|c|c|c|c|c|}
\hline by the minors & +31.6 & +25.0 & -59.4 & +16.7 \\
\hline Total of crimes committed by the minors in groups & $\begin{array}{l}36 \\
+16.1\end{array}$ & $\begin{array}{l}41 \\
+13.9\end{array}$ & $\begin{array}{l}24 \\
-41.5\end{array}$ & $\begin{array}{l}12 \\
-50.0\end{array}$ \\
\hline $\begin{array}{l}\text { Total of crimes committed by the minors in a state of } \\
\text { alcoholic intoxication }\end{array}$ & $\begin{array}{l}15 \\
+25.3\end{array}$ & $\begin{array}{l}22 \\
+46.7\end{array}$ & $\begin{array}{l}6 \\
-72.7 \\
\end{array}$ & $\begin{array}{l}12 \\
+100.0\end{array}$ \\
\hline
\end{tabular}

Positive trends in reduction of the number of crimes in 2018-2019 committed by the adolescents were secured owing to the individualized preventive work of the law enforcement officers and other entities within the preventive system.

In order to reduce further the indicators of the juvenile delinquency, slash the number of adolescents and families in socially dangerous situations, it is required to strengthen the interagency interaction of authorities and institutions of the preventive system.

The Federal State Institution Probation Department for Federal Prison Service (hereinafter referred to as FKU UII UFSIN) of Russia in Magadan Oblast (FKU UII UFSIN, 2019) is the authority that implements the penal sentences and exercises the criminal legislation measures in relation to the convicts without social isolation. The main objectives of FKU UII UFSIN are to conduct individualized preventive work with the minors, correct their behavior and provide the required assistance in relational adaptation in the society, as well as preventing their return to crime.

The total of the registered with UII UFSIN over the past three years is as follows:

- 2017: 63 of the minors (compulsory labor - 17, corrective labor - 1, suspended sentences 38 , condemned to confinement -6 , house imprisonment as imposed pre-trail restraint - 1);

- $2018-45$ of the minors (compulsory labor -9 , corrective labor -1 , suspended sentences 28 , condemned to confinement -6 , house imprisonment as imposed pre-trail restraint - 1);

- 10 months of 2019 - 20 of the minors (compulsory labor -4 , corrective labor -3 , suspended sentences -13 , condemned to confinement -0 , house imprisonment as imposed pre-trail restraint - 0 ).

For the reporting period of 2019 , there were no cases of return to crime committed by the minors after registration with UII UFSIN (2018 - 0, 2017 - 0, 2016 - 1).

One of the main reasons leading to commitment of the crimes by the minors is the criminal personality orientation in teenagers arising from the family circumstances, conditions of upbringing accepted in them, role models of parents, absence of the fear of responsibility for committing an illegal act, as well as the reluctance to study or work and embark on the path of reformation.

The main task of the authority is to conduct the personalized preventive work with such category of citizens, and to keep the teenager from making the faux pas in the society, to provide conditions for their reformation and further development as individuals, and to prevent them from return to crime.

In order to promote the activities on prevention of the delinquency and return to crime among the juvenile offenders, UII UFSIN joins forces with the agencies and institutions of the preventing system of the juvenile neglect and delinquency, as well as with the public associations (i.e. the Magadan and Sinegorsk Diocese of the Russian Orthodox Church; the State Healthcare Institution Magadan Regional Drug Abuse Clinic; the Ministry of Labor and Social Policy of Magadan Oblast; the Magadan State Funded Educational Institution (MBOU) of the city of Magadan Open (shifttype) general education school; Russian Union of Youth LLC; the Center for psychological and pedagogical medical and social assistance; the Children's Youth Center; the Department of Culture of the City Hall of Magadan; the Ombudsman for the Children's Rights in Magadan Oblast; the public organization National Parent Association). 
UII UFSIN of Russia in Magadan Oblast introduces various preventive measures as part of their preventive work, namely:

- carries out different types of preventive activities (meetings between the juvenile offenders and employees of the State Inspectorate for Road Traffic Safety (GIBDD) of the Ministry of Internal Affairs of Russia in Magadan Oblast, the Ombudsman for the Children's Rights, with the psychologists from the Drug Abuse Clinic and facilitators, representatives of the public organizations, youth and volunteer movements);

- collaboration with the juvenile affairs services of the internal affairs in the districts takes place, the joint surprise inspection to the places of residence of the juvenile convicts are scheduled in order to check on them and their compliance with the charges imposed by the court;

- educational activities are conducted by a psychologist representing the psychological support team.

Particular role in prevention of the juvenile neglect and delinquency is assigned to the Prosecutor's Office of Magadan Oblast, which oversees the activities of the agencies of the preventive system. Prosecutors are directly involved in ongoing legal education of the adolescents and their parents (lawful guardians), at workshops and interagency meetings in educational, health care and social welfare institutions.

Collection and analysis of the data pertaining to the legitimacy status in the sphere of organizational management on the prevention of the juvenile delinquency is implemented; the measures are taken to ensure efficient interaction, exchange of the statistical and other information among the state authorities, local self-governments, other agencies of the preventive system, and public organizations.

The Ministry of Internal Affairs of Russia in Magadan Oblast notifies on a daily basis the regional prosecutor's office on actual status as regards the incidents. The circumstances of each incident involving the minors are investigated and evaluated by the prosecutors, and, if deemed necessary, the response measures are taken.

The Prosecutor's Office of the city of Magadan carries out an interagency exchange of information as stipulated by the agreement on cooperation concluded on November 25, 2016, to identify children in socially dangerous situations. The parties to this agreement are representatives of the committee on the affairs of the minors and protection of their rights, internal affairs agencies, education authority, and public health and social protection of the population. The parties are liable to immediately notify one another of any case threating the life or health of the minors in order to quickly respond and protect their rights.

Ensured is the supervision over compliance with the regulatory legal acts in effect issued by the state and local authorities, and governing the activities of the agencies and institutions of the juvenile neglect and delinquency preventive system, combating the growth of the criminal subculture among the youth and preventing their involvement into destructive trends.

In 2019, the Prosecutor's Office of Magadan Oblast revealed 1867 violations of the law in the field of the protection of the rights and legitimate interests of the minors. Over 10 months of 2019, the following prosecutorial response measures were enforced:

- court lawsuits filed 440 (versus 190 over the same period last year);

- submissions made 228 (versus 208 over the same period last year);

- protests registered 28 (versus 57 over the same period last year);

- criminal cases opened by the prosecutor's order 4 (versus 1 over the same period last year). 
The composition of the offenses identified by the prosecutors in the field of the protection of the rights and legitimate interests of the minors for 2019 looks as follows:

- 958 related to life, health, protection of family, motherhood and childhood;

- 631 related to education;

- 170 related to compliance with housing rights;

- 67 related to prevention of neglect and delinquency;

- 41 related to labor rights protection.

The measures taken by the prosecutor response in view of the adjusted performance of the authorities within the preventive system of the juvenile neglect and delinquency in part of protecting the rights and legitimate interests of children, preventing the occurrence of the juvenile delinquency have generated positive results, namely the reduction in the total of crimes committed by the minors over the 9 months of 2019 by $10 \%$ (57 crimes versus 63 over the 9 months of 2018) (Gekhova, 2019).

To summarize the issues discussed, it should be noted that the regional legislation of Magadan Oblast in overall complies with the policy of the federal legislator. Due attention is paid to the prevention of the juvenile delinquency and crime. All agencies and institutions of the juvenile neglect and delinquency preventive system are involved into the interagency cooperation, and focus on representing the interests of the minors, with their responsibility to curb the risk for a teenager to be likely involved in antisocial and criminal activities, and to lower the rate of the juvenile delinquency.

Agencies and officials liable by virtue of law to prevent the juvenile neglect and delinquency should execute their functions on the grounds of the principles of coordination, interaction, and information exchange and sharing experience. A comprehensive and thorough analysis of causes and conditions conducive to the juvenile neglect and delinquency and timely implementation of the preventive measures must be carried out.

The measures taken in relation to the minors to prevent their commission of offense, return to misconduct and crime comprise organization of the leisure time, afterschool employment, involvement in the socially significant activities, and fashioning a healthy lifestyle.

\section{References}

Act of legislation of Magadan Oblast dd. December 24, 2012 no. 1573-OZ on the State Youth Policy in Magadan Oblast (rev. dd. May 3, 2018). (2012, December 26). Magadan. Pravda. (in Russian)

Act of legislation of Magadan Oblast dd. July 17, 2018 no 2290-OZ on Specific Issues of Crime Prevention in Magadan Oblast (rev. dd. March 18, 2019). (2018, July 26). (in Russian). Retrieved from http://docs.cntd.ru/document/543568993

Act of legislation of Magadan Oblast dd. November 24, 2012 no. 1573-OZ on Measures to Prevent the Juvenile Neglect and Delinquency (enacted by the Magadan Oblast Council (Duma) on October 31, 2008) (rev. dd. May 03, 2018). (2008, November 25). Magadan. Pravda. (in Russian)

Convention on the Rights of the Child. (1989, November 20). Retrieved from https://www.ohchr.org/en/professionalinterest/pages/crc.aspx

Decree of the Government of Magadan Oblast dd. August 21, 2017 no. 829-pp on Ratification of the State Program of Magadan Oblast on Safety, Prevention of Delinquency, Corruption and Combating the Illicit Drug Trafficking in Magadan Oblast for 2018-2024 (rev. dd. June 29, 2018). (2017, September 26). Magadan. Pravda. (in Russian) 
Decree of the Government of Magadan Oblast dd. June 22, 2017 no. 594-pp on Ratification of the Norms and Procedures on Provision the Minors registered with the Institutions Administrating Prevention of the juvenile neglect and delinquency in Magadan Oblast with Free Food, Outfit, Shoes and Textile Products. (2017, June 27). Magadan. Pravda. (in Russian)

Decree of the Government of Magadan Oblast on the Government Committee of Magadan Oblast for the Affairs of the Minors and the Protection of their Rights dd. May 29, 2014 no. 453-pp (rev. dd. August 08, 2019). (2014, June 10). Magadan. Pravda. (in Russian)

Decree of the President of Russia dd. May 29, 2017 no. 240 on Pronouncing the years of 2018-2027 as the Decade of Childhood in the Russian Federation. (2017). Official Gazette of the RF. (in Russian). Retrieved from https://rg.ru/2017/05/29/prezident-ukaz240-site-dok.html

Federal Law dd. June 23, 2016 no. 182-FZ on Fundamental Principles of the System for the Delinquency Prevention in the Russian Federation. (2016). Official Gazette of the RF. (in Russian). Retrieved from https://rg.ru/2016/06/28/profilaktika-dok.html

Federal State Institution Probation Department for Federal Prison Service (FKU UII UFSIN) of the Russian Federation in Magadan Oblast. (2019). Information on measures taken to prevent the delinquency and repetition of crimes committed by the young convicts registered with the criminal executive inspection of the Federal Penitentiary Service of Russia in Magadan Oblast. (in Russian)

Gekhova, D. (2019). Extract from the speech delivered at the VI Open Forum Children are our Future. Family-School-Society, 2-10. (in Russian)

Kostenko, E. N. (2018). Objects of public prosecutorial supervision over implementation of the legal acts on the prevention of the juvenile neglect and delinquency. Sovrem. Right, 7-8, 2833. (in Russian)

Morley, E., Rossman, Shelli B., Kopczynski, M., Buck, J., \& Gouvis, C. (2000, November) Comprehensive Responses to Youth at Risk: Interim Findings from the Safe Futures Initiative. Office of Juvenile Justice and Delinquency Prevention.

On enactment of the Youth of Magadan Program for 2018-2022: Resolution of the Magadan City Hall dd. September 18, 2017 no. 3026 (2017, October 5). Vecher. Magadan. (in Russian)

On holding Public Hearings in line with the long-term purpose-oriented city program implementation on Delinquency Prevention in the municipality of the City of Magadan in 2011-2013: Resolution of the Magadan City Hall dd. August 24, 2010 no. 2515. (2010, August 26). Vecher. Magadan. (in Russian)

On Ombudsman for the Children's Rights in Magadan Oblast: Legislative Act of Magadan Oblast dd. July 22, 2015 no. 1923-O. (2015, June 30). Magadan. Pravda. (in Russian)

Purpose-oriented Program on Prevention of Delinquency in the municipality of the City of Magadan in 2006-2010: Resolution of the Magadan City Council dd. November 17, 2006 no. 93-D. (2007, February 08). Vecher. Magadan. (in Russian)

Resolution of the Government of the Russian Federation dd. July 06, 2018 no. 1375-r. on Implementation of the key actions plan until the year of 2020 within the context of the Decade of Childhood. (2018). Official Gazette of the RF. (in Russian)

Resolution of the Government of the Russian Federation dd. November 6, 2013 no. 995 on Enactment of approximate regulation on committees for the affairs of the minors and 
protection of their rights. (2013). Official Gazette of the RF. (in Russian). Retrieved from https://rg.ru/2013/11/11/deti-do18-site-dok.html

Resolution of the Governor of Magadan Oblast dd. August 08, 2016 no. 174-p (rev. dd. February14, 2018) on Interagency Committee for the Prevention of Offenses and Procedures in Emergency Situations in Recreation Places for Children to Ensure Safety of the Organized Groups of Children along the Routes for all means of transport (in conjunction with Regulation on Interagency Committee for the Prevention of Offenses and Procedures in Emergency Situations in Recreation Places for Children to Ensure Safety of the Organized Groups of Children along the Routes for all means of transport. (2016, August 16). Magadan. Pravda. (in Russian)

Russian Ministry of Internal Affairs in Magadan Oblast. (2019). On provision of the information on the juvenile delinquency situation in Magadan Oblast: in response to the enquiry from the Department of Law of the Northeastern State University on November 15, 2019 no. 50 / 61342 / (in Russian)

United Nations Guidelines for the Prevention of Juvenile Delinquency. (1990). Retrieved from http://hrlibrary.umn.edu/instree/j2ungpjd.htm

United Nations Standard Minimum Rules. (1985, November 29). Retrieved from https://www.ohchr.org/Documents/ProfessionalInterest/beijingrules.pdf

Xu, X., Li, D., Chu, Ch. M., Chng, G. S., \& Ruby, K. (2019, October 28). Understanding Changes in Youth Offenders' Risk Profiles: A Latent Transition Analysis. Youth Violence and Juvenile Justice (YVJJ), 1-19. 